\title{
Association between serum paraoxonase 1 activity and its polymorphisms with multiple sclerosis: A systematic review
}

\begin{abstract}
Aim and Background. Human serum paraoxonase (PON) is an enzyme that is synthesized by the liver and enters the bloodstream, and it is is transmitted by high-density lipoproteins (HDL). It has antioxidant properties and has the power to protect against factors such as lipid oxidation, low-density lipoprotein (LDL), very low density lipoprotein (VLDL), organophosphate pesticides, neurotransmitters, and a number of drugs. In this study, due to the activity of PON1 in the brain and its antioxidant effects on the reduction of neurological disorders in the central nervous system, the role of PON1 and its polymorphisms related to multiple sclerosis has been examined with a view to enhance treatment methods.

Materials and Methods. This article is a systematic review; In this study, the role of PON1 and its polymorphisms in multiple sclerosis (MS) has been investigated. Articles published in Persian and International databases of SID, Google Scholar, ISI, Magiran, PubMed, Scopus, IranDoc, Science Direct, and Iran medix were examined, using the search keywords of Paraoxonase 1, polymorphism, multiple sclerosis, and PON1.

Findings. PON1 is undoubtedly a potential factor in the pathogenesis of neurological disorders, and it plays an important role in protecting antioxidants in the blood. Oxidative stress and lipid peroxidation are factors in the pathogenesis of MS. Both inflammatory cytokines and oxidative stress have a detrimental effect on PON1. However, reducing the activity of PON1 may help to restore the pathogenesis of the disease.

Analysis. Decreased PON1 activity and PON1 polymorphism have been associated with several neurological diseases, including ischemic stroke, white matter lesions (WML's), amyotrophic lateral sclerosis (ALS), dementia, and Parkinson's disease. PON1-55M alleles in Italians and PON1-192Q alleles in Poles were associated with a high risk of MS. Moreover, PON1-55 and PON1-192 polymorphisms were not associated with MS onset age, nor its evolutionary type.
\end{abstract}

Keywords: Multiple Sclerosis, Paraoxonase 1, Polymorphisms, Systematic Review

\section{Introduction}

Multiple sclerosis (MS) is one of the most common neurological disorders, occurring mainly in young adults and more commonly in women. Multiple sclerosis is a chronic inflammatory disease characterized by demyelinating lesions in the brain, spinal cord, and optic nerve [1]. Multiple sclerosis is a disease of young people and is most commonly diagnosed between the ages of 20 and 40, although it may be found in younger or older people [2]. Women are two to three times more likely than men to get MS [3].

Paraoxonaz 1 (PON1) is a hydrolytic enzyme with a wide range of substrates and the ability to protect against lipid oxidation. Despite the large number of compounds that can be hydrolyzed by paraoxonease, the biological substrates associated with this enzyme are not yet known [4]. In many cases, aryl ester hydrolysis is measured in biological samples to achieve PON1 levels [5].

There are currently three known members of the paraoxonase family: paraoxonase 1 (PON1), paraoxonase 2 (PON2), and paraoxonase 3 (PON3), which are encoded by three separate genes on a single chromosome [6]. All three members of the human paraoxonase family have $70 \%$ and $60 \%$ similarity in their nucleotides and amino acids respectviely [7]. Studies on the enzymatic activity of 
paraoxonase, in addition to organophosphatase and ester activities, have also shown lactonizing activity $[5,8]$. The relationship between MS and oxidative stress of lipoproteins has been examined in the study of cholesterol transfer in [9]. It has been suggested that increasing the number of oxidized HDL particles due to reduced PON activity may not protect LDL against oxidation, and thus increases the risk of atherogenesis $[10,11]$. Decreased PON1 activity in MS patients compared to healthy individuals was observed in a study by Ferretti et al. (2005) [12].

Due to the high number of people with the multiple sclerosis disorder, and the important role of PON1 in this disease, this study attempts to investigate the role of PON1 and polymorphisms related to multiple sclerosis. The findings of this study may benefit improved treatment methods for the MS patients. Moreover, a systematic review of all available research works and their combined results can provide a clear summary to inform future research related to PON1 and its impacts on the health of the nervous system.

\section{Method}

This article is a systematic review; in this study, the role of PON1 and its polymorphisms in multiple sclerosis was investigated. In order to find related studies, the national and international databases of SID, ISI, Magiran, PubMed, Scopus, IranDoc, Science Direct, Iran medix, and Google Scholar were searched without a time limit. The search was carried out using the Persian equivalent keywords paraoxonase 1, polymorphism, MS, multiple sclerosis. MeSH topic based medical keywords were used to search the international databases; the keywords used were paraoxonase 1, polymorphism, multiple sclerosis, and PON1. Initially, all related articles were collected and then a list of abstracts was prepared. After anonymizing the articles by removing the the names of the magazine and the author(s), the full text of the articles were made available to reviewers. Each article was independently examined by two reviewers, and if the article was to be excluded, the reason for its exclusion was noted. In case of disagreement between the two reviewers, the article was assessed by a third reviewer. In this study, all research works that focused on the role of PON1 and polymorphisms in multiple sclerosis without a time limitat, and based on the PRISMA guidelines were systematically reviewed. Specifications of the meta-analyzed studies are reported in Figure 1. 


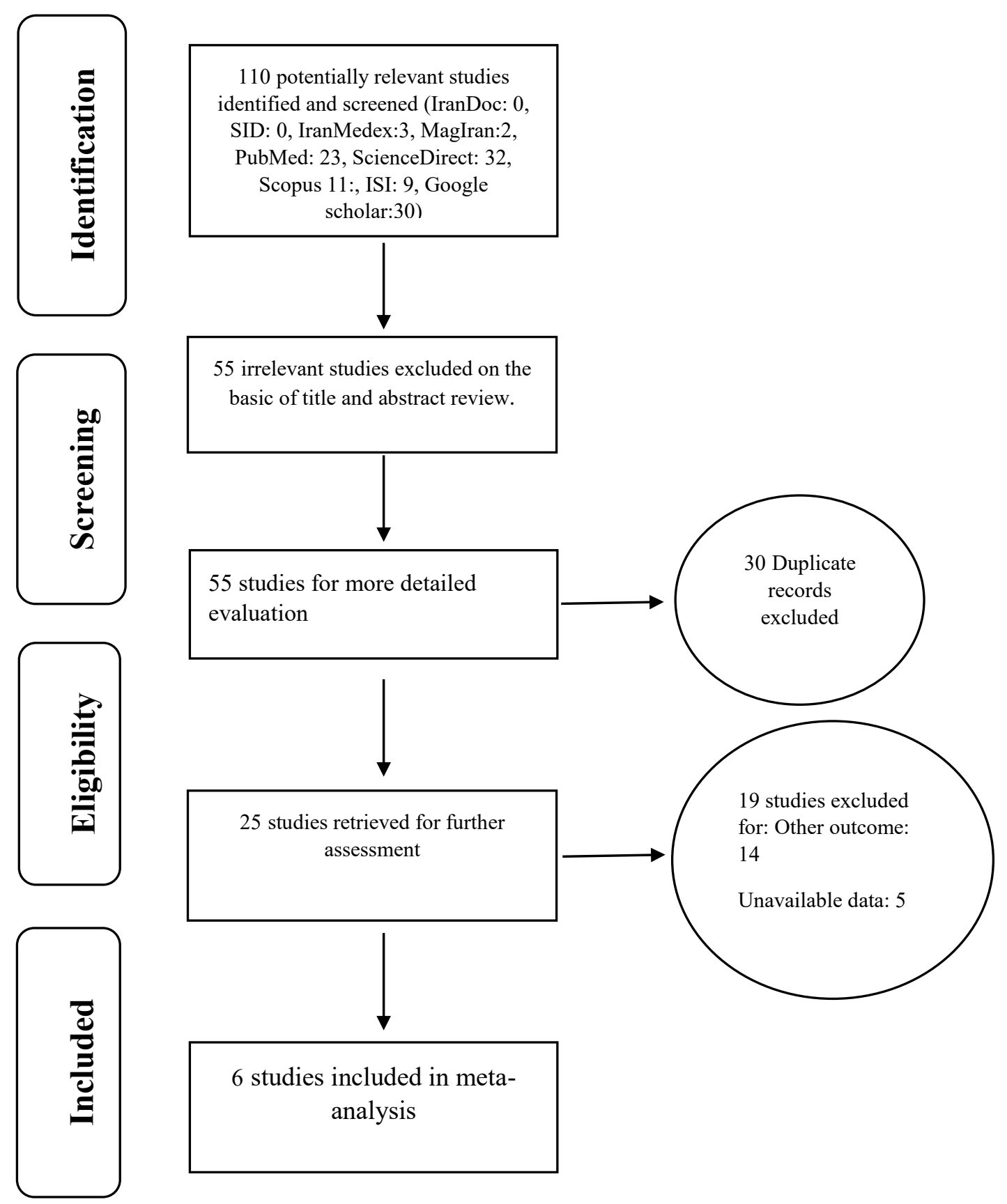

Figure 1: PRISMA flow diagram demonstrating the study selection process in this systematic review and meta-analysis.

\section{A brief history of paraaxonase}

In 1946, Abraham Mazur found that diisopropyl fluorophosphate (DFP) was hydrolyzed by extracts from various human tissues and rabbits [13]. This discovery led to the initial identification of the paraoxonase serum enzyme in humans. Aldridge divided esterases into two categories, A and B: Btype esterases that are inhibited by intermediation with substrates, and A esterases that hydrolyze substrates. Therefore, paraoxonase (PON1) was classified as A, due to its ability to hydrolyze paraoxon, the natural metabolite of parathion (Figure 2) [14]. 


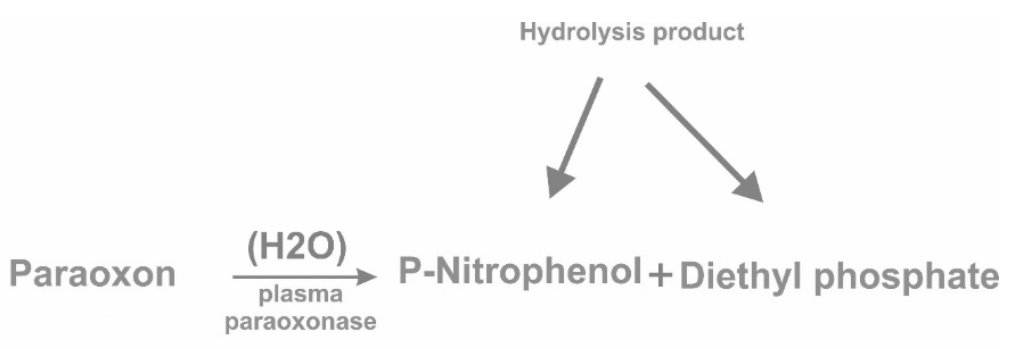

Figure 2: Paraoxon hydrolysis by the enzyme paraxonase

\section{Paraaxonase 1}

Human serum paraoxonase (EC 3.1.8.1-Aryldialkylphosphatase) is a glycosylated protein with 354 amino acids and an atomic mass of $43 \mathrm{kDa}$. PON1 was first identified in mammals. Then it was observed in domesticated fowl (chicken), osteichthyes (fish) and even invertebrates, although its activity in insects, birds and fish is very limited [15]. Human serum paraoxonase is likely to be combined with phosphate binding protein (HPBP), before it is secreted into the bloodstream (16).

\section{Paraoxonase 1 and other members of this family}

In 1996, Primo-Parmo et al. introduced two other members of the family, PON2 and PON3 [6]. The paraoxonase 2 gene is located on chromosome 7 in humans and in mice on chromosome 6 , and unlike paraoxonase 1, paraoxonase 2 is not glycosylated. In 2005, PON1 was shown to exclusively hydrolyze organophosphate substrates, while paraoxonease 3 hydrolyzed larger substrates such as spironolactone. All three enzymes are lactonases with separate or common substrates [8]. PON 1 and PON 3 are expressed in the liver and secreted into the blood, where they bind to HDL particles [17]. PON2 is not present in the blood, yet it is expressed in some tissues, including liver, lungs, brain, and heart tissues [18]. Genes related to paraoxonase are also known in plants, bacteria and fungi. There are more than $80 \%$ amino acid similarity of PON 1 in rabbits, mice, human, and at least $60 \%$ similarity between PON1, PON2 and PON3 in each of these species [7].

Paraoxonase 1 acts as a strong ester over several synthetic substrates, while PON2 and PON3 have almost no paraoxonase activity, though they present a high lactonase activity (5).

Table 1: Basic features of the paraoxonase family $(7,12,19)$

\begin{tabular}{|c|c|c|c|}
\hline Features & PON1 & PON2 & PON3 \\
\hline Amino acids & 355 & 354 & 354 \\
\hline \multirow[t]{2}{*}{ Tissue specificity } & \multirow[t]{2}{*}{ Liver } & $\begin{array}{l}\text { Ubiquitous in } \\
\text { lungs }\end{array}$ & Liver, \\
\hline & & $\begin{array}{c}\text { placenta, heart, } \\
\text { Liver }\end{array}$ & Kidney \\
\hline Localization & Plasma & Cells & Plasma \\
\hline \multirow[t]{2}{*}{ Activity } & $\begin{array}{l}\text { Paraoxonase } \\
\text { Lactonase }\end{array}$ & Lactonase & \multirow[t]{2}{*}{ Esterase } \\
\hline & Lactonase & Esterase & \\
\hline
\end{tabular}




\section{Molecular basis and structure of paraoxonase 1 (PON1)}

The gene for this enzyme is located on chromosome 7, band 7q21.3. PON1 in humans and mice gene includes 9 exons with approximately 25 to 26 kbases [20]. This enzyme maintains its end-N signal sequence, which creates a hydrophobic part to bind the enzyme to high-density lipoprotein (HDL). Paraoxonase has three residual cysteines, in positions 353,42 , and 284, the first and second forming a di-sulfide bridge, though the cysteine 284 is free [21].

The paraoxonase expressed in animal cells is glycosylated [22]. There are four strong $\mathrm{N}$ glycosylation sites in paraoxonase [7]. Glycosylation is not necessary for the hydrolytic activity of paraoxonase, however, it may be important in increasing solubility and stability, or in preventing its non-specific binding to cell membranes such as other HDL-bound enzymes (23). The exact structure and catalytic mechanism of the human paraoxonase 1 enzyme (HuPON1) is not yet known, however, there is a similar model to HuPON1 (6-blade butterfly structure of isopropyl fluoro phosphatase) (please see Figure 3). In this structure, each plate consists of four strands, the plates of which are arranged radially, and two calcium ions are located in the center, which are essential for stability and enzymatic catalysis [7].

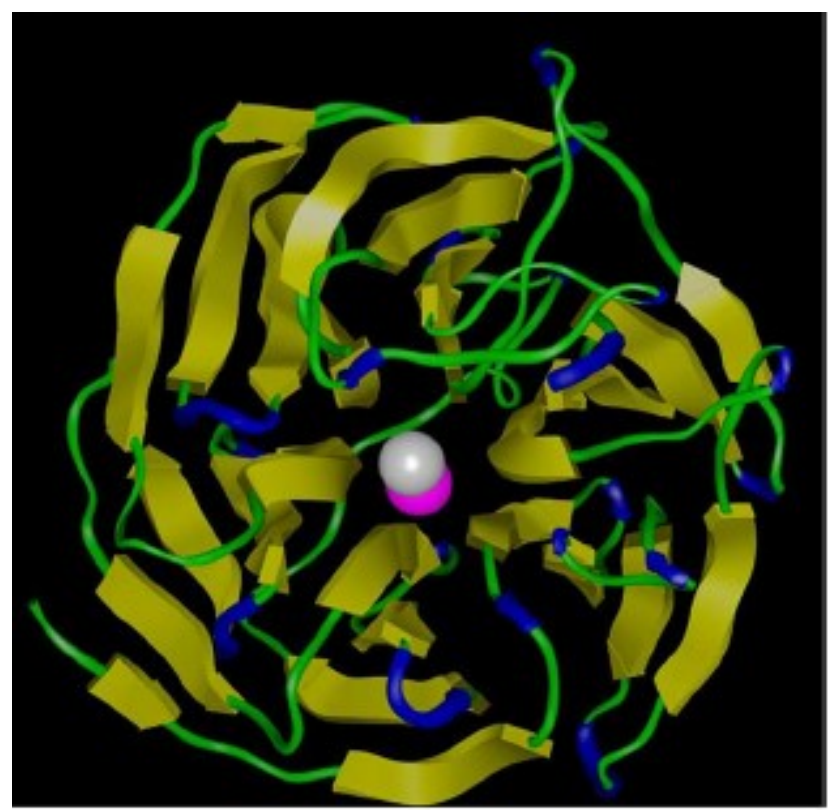

Figure 3: The crystalline structure of DFPase has been used as a model for the second structure of the human paraoxonase enzyme [24].

\section{Structural analysis - the activity of amino acid residues in the active site of the enzyme}

Methionine and glutathione amino acids are reduced in patients with multiple sclerosis, however, homocysteine, asymmetric dimethylarginine, and cysteine in patients with multiple sclerosis have not changed compared to the control groups. Methionine and glutathione appear to be important markers for the prognosis of multiple sclerosis [25]. The attempts to purify the enzyme have so far been unsuccessful [16]. However, by using mutations in the target sites, researchers have been able to identify many of the residues necessary for enzyme activity [24]. For instance, replacing histidine 115 with tryptophan $(\mathrm{W} 115 \mathrm{H})$ has caused a mutation that hydrolyzes paraoxone, yet this is unable to hydrolyze phenyl acetate (26). In addition, phenyl acetate competitively inhibits paraoxon hydrolysis by mutating $\mathrm{W} 115 \mathrm{H}$, indicating that both compounds bind to the same site on HuPON1. Y222F causes phenyl acetate hydrolysis by the enzyme, yet it is unable to hydrolyze paraoxone. Other findings suggest that the residual F222 is important for determining the substrate substrate nature of 
the enzyme, yet it does not have much of importance for the arylesterase activity. The results demonstrate that each of the phenyl acetate and paraoxon compounds is capable of competitively inhibiting another hydrolysis, indicating the presence of a single active site in HuPON1, which is responsible for the hydrolysis of phenyl acetate and paraoxon [26]. According to existing research, it is assumed that enzymatic catalysis of all substrates is carried out by two H134-H115 residues, so that the actual hydrolysis of the substrate is carried out by an activated water molecule [7]. While H115 is believed to be important for lactonase activity, the functional role of amino acid residues that are responsible for the hydrolase activity of organophosphates remains unknown. In the meantime, little attention has been paid to the chiral center (in the phosphorus molecule), and this can dramatically alter the toxicity of stereoisomerism (27). Nevertheless, discovering multiple mechanisms in an active position is essentially unique [28].

\section{Findings}

In the initial search, 110 articles were collected. Subsequently, 55 articles that were unrelated to the topic under discussion in this study were removed. Moreover, 30 duplicate articles and 19 articles due to lack of access to data and their low quality were also excluded. Finally, 6 studies were used for the final analysis (please see Figure 1). The characteristics of the papers included in this study are reported in Table 2.

Sidoti et al. (2007) conducted a case-control study to investigate the possible association of GI A111E, PON1 Q192R and L55M polymorphisms with the risk of multiple sclerosis. They found that people with GI / AE-EE and PON55 / LM-MM genotypes had a higher risk of developing MS compared to other genotypes. Italians with the PON55 / LM-MM genotype had a significantly higher risk than multiple sclerosis compared to other genotypes [29].

Jamroz-Wisniewska et al. (2009) examined the relationship between R / PON1 192Q polymorphism and multiple sclerosis in the Polish population. The results of their studies highlighted that PON1 activity was lower in patients with multiple sclerosis than in healthy individuals [30]. In the subgroup analysis of multiple sclerosis patients performed by Jamroz-Wisniewska. et al. patients with MS-SP were significantly older than patients with multiple sclerosis RR type. Similarly, the parameters of serum lipids, such as cholesterol, triglycerides, and LDL cholesterol, have been significantly increased in patients with SP-type multiple sclerosis compared to RR-type multiple sclerosis. There was no significant difference in PON1 activity between RR and SP subtypes of multiple sclerosis patients. The most common alleles in patients are QR / LL and in the control group, QQ / LM. No association was found between alleles associated with low PON1 activity and the prevalence of multiple sclerosis. In this study, there was no effect on serum PON activity in patients with MS and the control group. Since MS is more common in women, they compared PON1 activity between the genders. The results demonstrated that the mean values of enzyme activity were higher in women. However, there is no significant difference in PON1 activity between MS subtypes (RR and SP types of MS) [30].

Durfinova et al. (2015) argued that the mean age and level of triglycerides for the control group was significantly higher than the patient group. HDL cholesterol was significantly higher in patients compared to the control group. All other demographic characteristics in these groups were not statistically different. Their work has contributed to the view that the polymorphism of PON1-55 and PON1-192 is probably not a risk factor for MS. However, this conclusion requires further study in other populations [31].

Zakrzewska-Pniewska et al. (2013) discussed that genotypes and allele frequency in both patient and control groups were in Hardy-Weinberg equilibrium. The genotypes and frequency of alleles did not differ significantly between MS patients and the control group; moreover these were not associated 
with gender and age either. Moreover, their study demonstrated that PON1 and PON2 polymorphisms are not a risk factor for MS in the Polish population [32].

In another study, Moghtaderi et al. (2011) measured serum PON1 and arylesterase (ARE) activity in two equal groups (63 cases each) of MS patients and healthy individuals. The mean serum PON1 and ARE activity in the control group was $190.8 \pm 150.3 \mathrm{IU} / \mathrm{L}$ and $99.9 \pm 73.3 \mathrm{IU} / \mathrm{L}$ respectively, and in the patients group, this was $90.3 \pm 63.4 \mathrm{IU} / \mathrm{L}$ and $182.1 \pm 128.7 \mathrm{IU} / \mathrm{L}$ respectively. Comparison of allele distribution and allele frequency in both groups demonstrated no statistical difference for PON1Q192R and PON L55M polymorphisms. In the selected group of patients with MS in the relapsing phase, there was no significant difference in PON1 and ARE activities, however the mean serum enzyme activity was lower in MS patients [9].

According to the work of Ferretti et al. (2005), the activity of paraoxonase in the plasma of patients with MS was significantly lower than in the control group. Their study highlighted changes in lipoprotein peroxidation in MS, and evidence suggests that oxidative stress and disruption of the antioxidant system may play a role in MS [12].

Table 2: Demographic, clinical, and biochemical characteristics of patients with Multiple Sclerosis and healthy controls,
and genotype distributions and allele frequencies for PON1 Q192R and L55M polymorphisms in patients with multiple
sclerosis compared with healthy subjects. SD, standard deviation; EDSS, Expanded Disability Status Scale; HDL, high-
density lipoprotein; LDL, low-density lipoprotein; PON1: Paraoxonase 1.

\begin{tabular}{|c|c|c|c|c|c|c|}
\hline Author Year & $\begin{array}{c}\text { M } \\
\text { Durfinov } \\
\text { a } 2015 \\
{[31]}\end{array}$ & $\begin{array}{c}\text { A } \\
\text { Jamroz- } \\
\text { Wisnie } \\
\text { wska } \\
2009 \\
{[30]}\end{array}$ & $\begin{array}{c}\text { Zakrze } \\
\text { wska- } \\
\text { Pniews } \\
\text { ka 2013 } \\
{[32]}\end{array}$ & $\begin{array}{l}\text { A Moghtaderi } \\
2011 \text { [9] }\end{array}$ & $\begin{array}{l}\text { A Sidoti } \\
2007 \text { [29] }\end{array}$ & $\begin{array}{l}\text { G Ferretti } \\
2005[12]\end{array}$ \\
\hline City & Slovakia & Poland & Polska & Iran & Italia & Italia \\
\hline $\begin{array}{l}\operatorname{Age} \pm \text { SD } \\
\text { (patient/cont } \\
\text { rol) }\end{array}$ & $\begin{array}{c}39.9 \pm \\
9.47 / 49 . \\
6 \pm 12.25\end{array}$ & $\begin{array}{c}36 / 3 \pm \\
12.6 / 39 \\
6 \pm 9.2\end{array}$ & $\begin{array}{c}36.8 \pm 1 \\
0.5 / \\
55.3 \pm 1 \\
7.3\end{array}$ & $\begin{array}{c}32.3 \pm 9.2 / 42.3 \pm 14 \\
3\end{array}$ & $\begin{array}{c}41 \pm / 8.4 / 4 \\
4 \pm / 11.4\end{array}$ & $\begin{array}{l}38.2 \pm / 3.6 / \\
31.5 \pm / 2.9\end{array}$ \\
\hline $\begin{array}{l}\text { Sample size } \\
\text { (patient/cont } \\
\text { rol) }\end{array}$ & $80 / 98$ & $40 / 55$ & $\begin{array}{c}221 / 66 \\
1\end{array}$ & $63 / 63$ & $209 / 213$ & $24 / 89$ \\
\hline $\begin{array}{l}\text { Disease } \\
\text { duration } \pm \\
\text { SD (years) }\end{array}$ & $\begin{array}{c}6.13 \pm 3.1 / \\
-\end{array}$ & $\begin{array}{l}10.8 \pm 6 . \\
4 /-\end{array}$ & $\begin{array}{c}7.70 \pm \\
6.8 /-\end{array}$ & $3.8 \pm 1.4 /-$ & - & $3.1 \pm / 1.8$ \\
\hline $\begin{array}{l}\text { Total } \\
\text { cholesterol } \\
\text { (patient/cont } \\
\text { rol) }\end{array}$ & $\begin{array}{l}4.86 / 4.7( \\
\mathrm{mM})\end{array}$ & $\begin{array}{c}270 \pm \\
54 / 192 \\
\pm \\
61(\mathrm{mg} / \mathrm{d} \\
\mathrm{L})\end{array}$ & - & $\begin{array}{c}198.7 \pm 39.1 / 187.1 \pm \\
41.5(\mathrm{mg} / \mathrm{dL})\end{array}$ & - & $\begin{array}{l}172.5 \pm / 9.6 / \\
166.5 \pm / 6.8\end{array}$ \\
\hline $\begin{array}{l}\text { HDL- } \\
\text { cholesterol } \\
\text { (patient/cont } \\
\text { rol) }\end{array}$ & $\begin{array}{l}1.425 / 1.2 \\
6(\mathrm{mM})\end{array}$ & $\begin{array}{c}60 \pm \\
20 / 58 \pm \\
23(\mathrm{mg} / \mathrm{d} \\
\mathrm{L})\end{array}$ & - & $\begin{array}{c}39.8 \pm 8.7 / 43.7 \pm 6.7( \\
\mathrm{mg} / \mathrm{dL})\end{array}$ & - & $\begin{array}{c}50.3 \pm / 3.6 / 58 . \\
3 \pm / 3.0\end{array}$ \\
\hline
\end{tabular}




\begin{tabular}{|c|c|c|c|c|c|c|}
\hline $\begin{array}{l}\text { LDL- } \\
\text { cholesterol } \\
\text { (patient/cont } \\
\text { rol) }\end{array}$ & $\begin{array}{l}2.93 / 3.01 \\
(\mathrm{mM})\end{array}$ & $\begin{array}{c}187 \pm \\
59 / 135 \\
\pm \\
50(\mathrm{mg} / \mathrm{d} \\
\mathrm{L})\end{array}$ & - & $\begin{array}{c}125.5 \pm 36.9 / \\
114.3 \pm 35.7(\mathrm{mg} / \mathrm{dL} \\
)\end{array}$ & - & $\begin{array}{l}96.3 \pm / 8.5 / \\
84.5 \pm / 7.2\end{array}$ \\
\hline $\begin{array}{l}\text { Triglycerides } \\
\text { (patient/cont } \\
\text { rol) }\end{array}$ & $\begin{array}{l}1.24 / 1.76 \\
(\mathrm{mM})\end{array}$ & $\begin{array}{c}81 \pm \\
33 / 79 \pm \\
50(\mathrm{mg} / \mathrm{d} \\
\mathrm{L})\end{array}$ & - & $\begin{array}{c}166.8 \pm 78.5 / 131.1 \pm \\
65.8(\mathrm{mg} / \mathrm{dL})\end{array}$ & - & $\begin{array}{c}129.2 \pm / 8.1 / 1 \\
18.3 \pm / 7.5\end{array}$ \\
\hline $\begin{array}{l}\text { EDSS(patien } \\
\text { t) }\end{array}$ & $\begin{array}{l}2.84 \pm \\
1.06\end{array}$ & $\begin{array}{c}5.8 \pm \\
0.9\end{array}$ & $\begin{array}{l}\text { EDSS } \\
<3.5\end{array}$ & $2.7 \pm 0.5$ & - & $2.4 \pm / 0.5$ \\
\hline $\begin{array}{l}\text { PON1- } \\
\text { R/R(patient/ } \\
\text { control) }\end{array}$ & 27.3/9.2 & $\begin{array}{c}15.5 / 27 \\
5\end{array}$ & $\begin{array}{c}6.3 / 6.6 \\
5\end{array}$ & $14.3 / 15.9$ & $1.9 / 0.5$ & - \\
\hline $\begin{array}{l}\text { PON1- } \\
\text { Q/R(patient/ } \\
\text { control) }\end{array}$ & $45.5 / 37.8$ & - & $43 / 38.1$ & $30.2 / 34.9$ & $7.6 / 3.7$ & - \\
\hline $\begin{array}{l}\text { PON1- } \\
\text { Q/Q(patient/ } \\
\text { control) }\end{array}$ & $27.3 / 53.1$ & $\begin{array}{l}84.5 / \\
72.5\end{array}$ & $\begin{array}{l}50.7 / 55 \\
.1\end{array}$ & $55.6 / 49.2$ & $90.5 / 95.8$ & - \\
\hline $\begin{array}{l}\text { PON1- } \\
\text { L/L(patient/c } \\
\text { ontrol) }\end{array}$ & $61.4 / 39.8$ & - & $\begin{array}{l}43.4 / 41 \\
.5\end{array}$ & $39.7 / 50.8$ & $38.3 / 86$ & - \\
\hline $\begin{array}{l}\text { PON1- } \\
\text { L/M(patient/ } \\
\text { control) }\end{array}$ & $34.1 / 55.1$ & - & $\begin{array}{l}45.3 / 48 \\
.4\end{array}$ & $15.9 / 17.5$ & $49.3 / 4$ & - \\
\hline $\begin{array}{l}\text { PON1- } \\
\text { M/M(patient } \\
\text { /control) }\end{array}$ & $4.5 / 5.1$ & - & $\begin{array}{c}11.3 / 10 \\
.1\end{array}$ & $44.4 / 31.7$ & $12.4 / 10$ & - \\
\hline
\end{tabular}

\section{Discussion}

Human serum paraoxonase 1 (PON1) is a polymorphic enzyme encoded by the PON1 gene, and is an aryldialkylphosphatase that is mainly synthesized in the liver and plays an important role in the metabolism of several organophosphorus compounds such as pesticides, neurotoxins and aryl esters. [33]. Increase in uric acid and decrease in glutathione concentration in plaques, decrease in alphatocopherol level in plaques and increase in alpha-tocopherol level in distant white matter and normal ascorbic acid, cysteine, tyrosine and tryptophan in plaques and in distance white matter has been observed in MS patients compared to the control group [34]. Research works have shown that the activity of paraoxonase-1 in the plasma of patients with multiple sclerosis has decreased [35].

The high diversity in the range of activities of PON1 has been attributed to several polymorphisms in the gene. A number of polymorphisms that are not officially titled yet have impacted PON1 activities; examples of these polymorphisms include: replacing a leucine to methionine at position 55 (L55M, rs854560, c.220 T> A according to the GenBank Accession Number NM 000446) and replacing a 
glutamine with arginine at 192 (Q192R, rs662, c.632 A> G according to the GenBank Accession Number NM 000446) [20,36, 37].

In the paraoxonase coding region, there are two polymorphisms in positions (Gln / Arg) 192 and (Met / Leu) 55. The polymorphism of Q192R has been extensively studied, since its two allozymes present different catalytic orientations and activities to a number of substrates. The change in structure caused by the displacement of these amino acids changes the activity of the enzyme. Amino acid $192 \mathrm{R}$ is an important residue in the active site, for instance, paraoxone hydrolysis is 6 times faster by isoform 192 R compared to isoform 192 Q, however, some organophosphates and lactones are hydrolyzed faster by isoform $192 \mathrm{Q}$ [38]. Arylesterase activity and PON1 antigen concentration are similar for both isozymes. It has recently been shown that the position of 192 in paraoxonase becomes active for HDL connection. The Q192 allele binds to HDL three times less than the R allele, thereby reducing its stability, lipolactonase activity, and cholesterol excretion from macrophages [39]. In a study of 1527 women, it was demonstrated that isozym $\mathrm{R}$ was a major factor in the paraoxonase activity of PON1 [40].

Q192R polymorphism leads to the replacement of glutamine with arginine at position 192 [41]. It also affects the ability of the enzyme to protect LDL against oxidizing agents, so that the Q isoform provides the most protection against LDL oxidation. Frequent association of $192 \mathrm{R}$ alleles with vascular diseases indicates a lower effectiveness of this alloenzyme in the metabolism of oxidized lipids or its lower stability compared to 192 Q alleles; there exist experimental reasons for both of these differences [42]. By converting a leucine to methionine at position 55, polymorphism $55 \mathrm{~L} / \mathrm{M}$ did not affect the interaction of paraaxonase with its substrates, but did affect serum enzyme concentrations and activity (43). The activity of the M isoform is less than that of the L isoform, though it is not clear whether this low activity is due to its low stability, or due to the imbalance of its strong affinity with the $-108 \mathrm{C} / \mathrm{T}$ polymorphism in the gene promoter. When both nucleotides are in the -108 position, the LL genotype is more prone to serum paraoxonase levels than the MM genotype [44]. The L55 isoform is more stable and resistant to proteolysis, which may be a reason to associate it with a higher serum level of paraoxonase. Paraoxonase is also able to hydrolyze diazoxon which is the active metabolite of diazinon. This organophosphate, that is used to wash and disinfect animals, causes disease in some farmers. In a study that assessed the association between farmers who used diazinon, and polymorphisms Q192R and M55L, it was found that the patients were more likely to have at least one R allele or both LL alleles. People holding other alleles had acceptable health despite performing the same activities that exposed them to the same substance [45]. Paraoxonase 1 enzyme has several substrates, among which paraoxon and phenyl acetate are used as substrates to measure enzyme activity in a laboratory. The effect on paraoxon is referred to as paraoxonase activity and the effect on phenyl acetate is referred to as the arylesterase activity (which is more indicative of the amount of enzyme protein in plasma) [46]. Various polymorphisms in paraoxonase 1 are responsible for altering the activity and concentration of this enzyme, as well as for plasma HDL changes in different populations $[47,48]$. A study has shown that polymorphism $-108 \mathrm{C} / \mathrm{T}$ in the proximal region of the paraoxonase 1 promoter has caused a significant change in serum paraoxonase activity [46]. Changes in the area of $-108 \mathrm{C} / \mathrm{T}$ of the promoter are the most important genetic determinants of serum paraxonase 1 levels. Polymorphism $-108 \mathrm{C} / \mathrm{T}$ causes approximately 13 fold change in the enzyme activity and concentration in different individuals [49].

Serum paraoxonase 1 is a calcium-dependent esterase found in serum on high-density lipoprotein (HDL). The main function of PON1 is to hydrolyze lipid peroxides and protect LDL particles from oxidation [50]. Recent studies have shown changes in lipoprotein levels in patients with neurological diseases [51]. Moreover, decreased PON1 activity and polymorphism have been associated with several neurological diseases, including ischemic stroke, white matter lesions, amyotrophic lateral sclerosis (ALS), dementia, and Parkinson's disease (50, 52-54). 
Multiple sclerosis (MS) is a chronic degenerative disease of the central nervous system (CNS) characterized by inflammation, demyelination, decreased oligodendrocytes, gliosis, and axonal pathology [55]. Previous studies have shown the role of oxidative stress and lipid peroxidation in the pathogenesis of MS [56]. PON1 is a major detoxifier in organophosphates. Exposure to organophosphate is associated with neurological disorders in which acetylcholine (ACh) plays an important role. PON1 is certainly a potential factor in the pathogenesis of neurological disorders. In terms of ischemic stroke, studies show that PON1 activity is reduced in stroke patients. There is a significant inverse relationship between PON1 and carotid activity and cerebral atherosclerosis in stroke patients. Q192R PON1 polymorphism is associated with the risk of stroke: the presence of Al $\mathrm{R}$ increases this risk, especially in patients with high blood pressure [57]. Elevated lipid peroxide levels have been reported in cerebrospinal fluid (CSF) and MS patients' blood (58).

There is also PON1 activity in the brain that can exert antioxidant effects and reduce the progression of neurological disorders in the central nervous system [59]. Martinez et al. (2010) investigated the possible association of the PON1 genotype with the L55M and Q192R allele polymorphisms and the risk of multiple sclerosis in the Spanish Caucasian population [35]. They examined the frequency of PON1 and allele genotypes in 228 patients with multiple sclerosis and 220 patients as a control using PCR-restriction fragment length polymorphism (RFLP)-based analysis technique. They found no association between PON1 polymorphism and the risk of MS in the Spanish Caucasian population, and there was no relationship in terms of gender, age of onset and the course of the disease [35].

Cases of PON1 activity between MS patients and the control group were not found in other studies [9, 30]. This may be due to the different ages of patients with MS and the control group in the research groups, as well as the different stages of the disease (relapse, recovery), and other specific problems in the study samples [29]. The possible relationship between polymorphism PON1-55M / L and PON1192Q / R and the risk of MS in the populations of Italy [43], Poland [30], Spain [35] and Iran [9] has been examined. The PON1-55M allele in Italians and the PON1-192Q allele in Poles were associated with a high risk of MS [29]. According to a study by Jamroz-Wisniewska et al. (2009), PON1-55 and PON1-192 polymorphisms were not associated with MS onset age and MS evolutionary type [35]. Total cholesterol levels were significantly higher in patients with MS compared to the control group, and there was no significant difference in total cholesterol levels between different MS groups. Moreover, there was no significant difference in HDL cholesterol and triglycerides. LDL cholesterol was significantly higher in RR patients during recovery and in patients with advanced MS than in healthy individuals. As a result, the results of this study show that PON1 activity decreases during the relapse phase of the RR type of MS, yet it remains unchanged during recovery and progressive MS [30]. Both inflammatory cytokines and oxidative stress have a detrimental effect on PON1 [60]. However, decreased PON1 activity may contribute to an increase pathogenesis of the disorder [61, 62]. Newcombe et al. (1994) reported the presence of LDL products and oxidized lipid in primary demyelinating plaques and active in brain biopsy specimens in MS patients (please see Figure 3) [63]. 


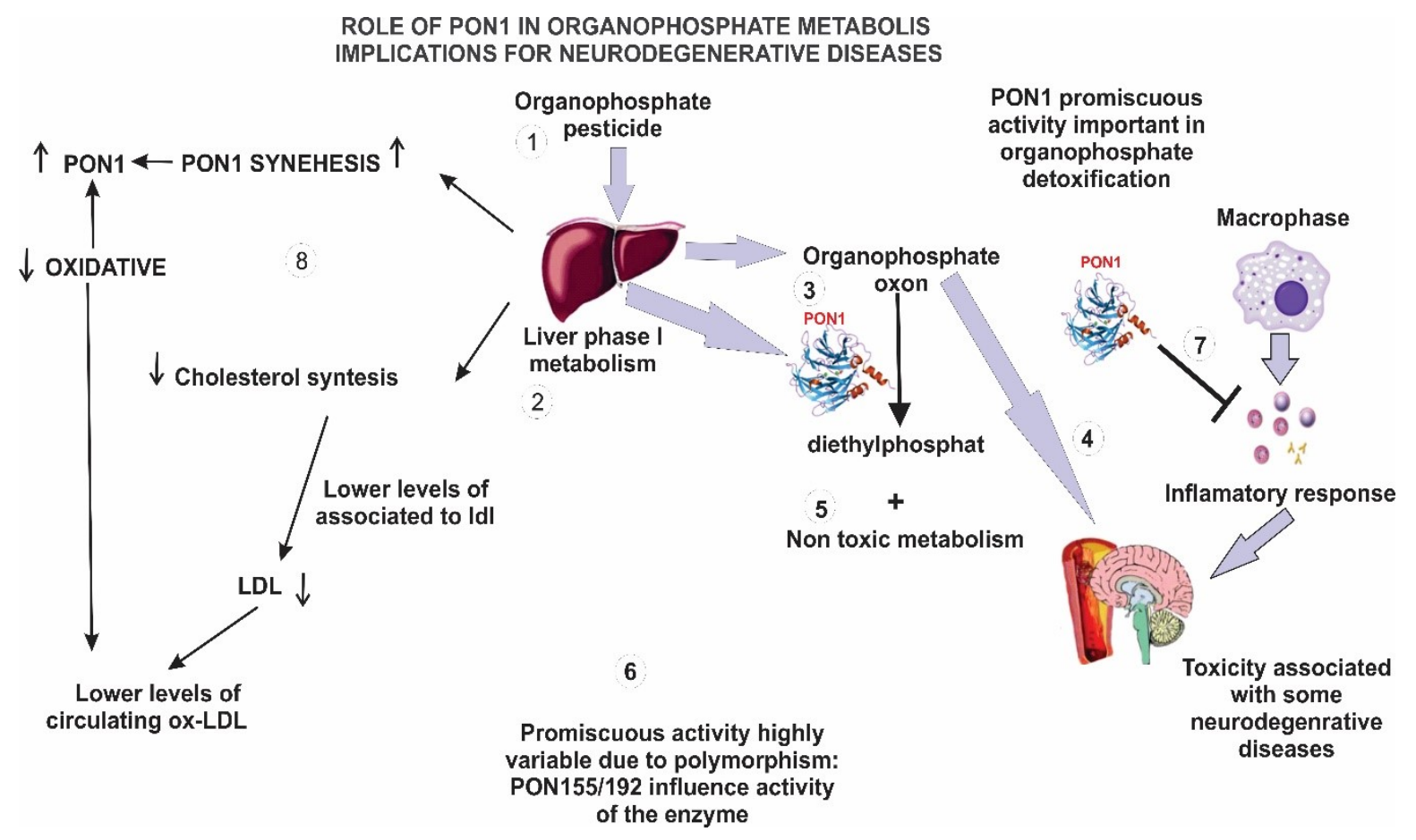

Figure 4: PON1 in toxicology: implications for neurodegenerative diseases. PON1 evolved from lactonases that have a key role in natural immunity, limiting quorum sensing lactones from bacteria. In evolution it acquired promiscuous esterase activities, hydrolyzing compounds of interest in toxicology. Organophosphate pesticides (1) are metabolized to their respective oxon by phase 1 metabolism in the liver $(2,3)$. These oxons are toxic due to their inhibition of acetylcholinesterase, which is associated with several neurodegenerative disorders (4). PON1 hydrolyzes paraoxon (oxon from parathion, from which the name derives) and oxons from many other organophosphates (5) and detoxifies them. Major polymorphisms in PON1 significantly change this activity (6) PON1 also exerts its salutatory action on macrophages and other inflammatory cells (7) which is mentioned in the discussion. oxidative stress related to antioxidant effect in PON1. ( $\uparrow$ increase; $\downarrow$ decrease).

\section{Conclusion}

PON1 is certainly a potential factor in the pathogenesis of neurological disorders, and PON1 plays an important role in protecting antioxidants in the blood. Oxidative stress and lipid peroxidation impacts the pathogenesis of MS. Both inflammatory cytokines and oxidative stress have a detrimental effect on PON1. However, reducing the activity of PON1 may help to restore the pathogenesis of the disease. Decreased PON1 activity and polymorphism have been associated with several neurological diseases. There is also PON1 activity in the brain that can exert antioxidant effects and reduce the progression of neurological disorders in the central nervous system. PON1 activity is lower in patients with multiple sclerosis than in healthy individuals. Italians with the PON55 / LM-MM genotype had a significantly higher risk than multiple sclerosis compared to other genotypes. Since MS is more common in women, PON1 activity has been compared between the gender groups, and the results demonstrate that the average levels of enzyme levels in women are lower. However, there is no significant difference in PON1 activity between MS subtypes (RR and SP types of MS). The possible relationship between PON1-55M / L and PON1-192Q / R and the risk of MS in the populations of Italy, Poland, Spain and Iran has been investigated. PON1-55M alleles in Italians and PON1-192Q alleles in Poles are associated with high risk of MS. According to literature, PON1-55 and PON1-192 polymorphisms were not associated with MS onset age and MS evolutionary type. Due to the lack of definitive treatment for multiple sclerosis, increasing the awareness of patients with multiple sclerosis and using the right treatments can significantly reduce the issues that they face and can relatively help improvements of these patients. 


\section{References}

1. Nessler S, Brück W. Advances in multiple sclerosis research in 2009. Journal of neurology. 2010;257(9):1590-3.

2. Sluder JA, Newhouse P, Fain D. Pediatric and adolescent multiple sclerosis. Adolescent Medicine Clinics. 2002;13(3):461.

3. Marrie RA. Environmental risk factors in multiple sclerosis aetiology. The Lancet Neurology. 2004;3(12):709-18.

4. Litvinov D, Mahini H, Garelnabi M. Antioxidant and anti-inflammatory role of paraoxonase 1: implication in arteriosclerosis diseases. North American journal of medical sciences. 2012;4(11):523.

5. Khersonsky O, Tawfik DS. Structure- reactivity studies of serum paraoxonase PON1 suggest that its native activity is lactonase. Biochemistry. 2005;44(16):6371-82.

6. Primo-Parmo SL, Sorenson RC, Teiber J, La Du BN. The human serum paraoxonase/arylesterase gene (PON1) is one member of a multigene family. Genomics. 1996;33(3):498-507.

7. Harel M, Aharoni A, Gaidukov L, Brumshtein B, Khersonsky O, Meged R, et al. Structure and evolution of the serum paraoxonase family of detoxifying and anti-atherosclerotic enzymes. Nature structural \& molecular biology. 2004;11(5):412-9.

8. Draganov DI, Teiber JF, Speelman A, Osawa Y, Sunahara R, La Du BN. Human paraoxonases (PON1, PON2, and PON3) are lactonases with overlapping and distinct substrate specificities. Journal of lipid research. 2005;46(6):1239-47.

9. Moghtaderi A, Hashemi M, Sharafaddinzadeh N, Dabiri S, Moazeni-Roodi A, Ramroodi N, et al. Lack of association between paraoxonase 1 Q192R polymorphism and multiple sclerosis in relapse phase: a case-control study. Clinical biochemistry. 2011;44(10-11):795-8.

10. Aviram M, Rosenblat M, Billecke S, Erogul J, Sorenson R, Bisgaier CL, et al. Human serum paraoxonase (PON 1) is inactivated by oxidized low density lipoprotein and preserved by antioxidants. Free Radical Biology and Medicine. 1999;26(7-8):892-904.

11. Imai Y, Morita H, Kurihara H, Sugiyama T, Kato N, Ebihara A, et al. Evidence for association between paraoxonase gene polymorphisms and atherosclerotic diseases. Atherosclerosis. 2000;149(2):435-42.

12. Ferretti G, Bacchetti T, Principi F, Di Ludovico F, Viti B, Angeleri V, et al. Increased levels of lipid hydroperoxides in plasma of patients with multiple sclerosis: a relationship with paraoxonase activity. Multiple Sclerosis Journal. 2005;11(6):677-82.

13. Mazur A. An enzyme in animal tissues capable of hydrolyzing the phosphorus-fluorine bond of alkyl fluorophosphates. Journal of Biological Chemistry. 1946;164(1):271-89.

14. Aldridge $\mathrm{W}$. Two types of esterase (A and $\mathrm{B}$ ) hydrolysing p-nitrophenyl acetate, propionate and butyrate, and a method for their determination (1953) Biochem. J.53:110-7.

15. Draganov D, La Du BN. Pharmacogenetics of paraoxonases: a brief review. NaunynSchmiedeberg's archives of pharmacology.78-88:(1)369;2004 .

16. Morales R, Berna A, Carpentier P, Contreras-Martel C, Renault F, Nicodeme M, et al. Serendipitous discovery and X-ray structure of a human phosphate binding apolipoprotein. Structure. 2006;14(3):601-9.

17. Reddy ST, Wadleigh DJ, Grijalva V, Ng C, Hama S, Gangopadhyay A, et al. Human paraoxonase-3 is an HDL-associated enzyme with biological activity similar to paraoxonase-1 protein but is not regulated by oxidized lipids. Arteriosclerosis, thrombosis, and vascular biology. 2001;21(4.542-7:( 
18. Mochizuki H, Scherer SW, Xi T, Nickle DC, Majer M, Huizenga JJ, et al. Human PON2 gene at 7q21. 3: cloning, multiple mRNA forms, and missense polymorphisms in the coding sequence. Gene. 1998;213(1-2):149-57.

19. La Du BN, Aviram M, Billecke S ,Navab M, Primo-Parmo S, Sorenson RC, et al. On the physiological role (s) of the paraoxonases. Chemico-biological interactions. 1999;119:379-88.

20. Humbert R, Adler DA, Disteche CM, Hassett C, Omiecinski CJ, Furlong CE. The molecular basis of the human serum paraoxonase activity polymorphism. Nature genetics. 1993;3(1):736.

21. Hassett C, Richter RJ, Humbert R, Chapline C, Crabb JW, Omiecinski CJ, et al. Characterization of cDNA clones encoding rabbit and human serum paraoxonase: the mature protein retains its signal sequence. Biochemistry. 1991;30(42):10141-9.

22. Primo-Parmo SL, Sorenson RC, Teiber J, Du BNL. The Human Serum Paraoxonase/Arylesterase Gene (PON1) Is One Member of a Multigene Family. Genomics. 1996;33(3):498-507.

23. Aharoni A, Gaidukov L, Yagur S, Toker L, Silman I, Tawfik DS. Directed evolution of mammalian paraoxonases PON1 and PON3 for bacterial expression and catalytic specialization. Proceedings of the National Academy of Sciences. 2004;101(2):482-7.

24. Yeung DT, Josse D, Nicholson JD, Khanal A, McAndrew CW, Bahnson BJ, et al. Structure/function analyses of human serum paraoxonase (HuPON1) mutants designed from a DFPase-like homology model. Biochimica et Biophysica Acta (BBA) - Proteins and Proteomics. 2004;1702(1):67-77.

25. Bystrická Z, Laubertová L, Ďurfinová M, Paduchová Z. Methionine metabolism and multiple sclerosis. Biomarkers. 2017;22(8):747-54.

26. Yeung DT, Lenz DE, Cerasoli DM. Analysis of active-site amino-acid residues of human serum paraoxonase using competitive substrates. The FEBS journal. 2005;272(9):2225-30.

27. Yeung DT, Smith JR, Sweeney RE, Lenz DE, Cerasoli DM. Direct detection of stereospecific soman hydrolysis by wild-type human serum paraoxonase. The FEBS journal. 2007;274(5):1183-91.

28. Khersonsky O, Tawfik DS. Structure-Reactivity Studies of Serum Paraoxonase PON1 Suggest that Its Native Activity Is Lactonase. Biochemistry. 2005;44(16):6371-82.

29. Sidoti A, Antognelli C, Rinaldi C, D'Angelo R, Dattola V, Girlanda P, et al. Glyoxalase I A111E, paraoxonase 1 Q192R and L55M polymorphisms: susceptibility factors of multiple sclerosis? Multiple Sclerosis Journal. 2007;13(4):446-53.

30. Jamroz-Wisniewska A, Beltowski J, Stelmasiak Z, Bartosik-Psujek H. Paraoxonase 1 activity in different types of multiple sclerosis. Multiple Sclerosis Journal. 2009;15(3):399-402.

31. Durfinová MD̃, Bartová R, Procházková L', Petrleničová D, Sýkora P, Repiská V. Paraoxonase 1 activity and polymorphisms in multiple sclerosis patients. Biologia. 2015;70(12):1672-6.

32. Zakrzewska-Pniewska B, Nojszewska M, Róg T, Pniewski J, Dorobek M, Styczyńska M, et al. Polymorphisms of paraoxonase 1 and 2 genes and the risk of multiple sclerosis in the Polish population. Neurologia i neurochirurgia polska. 2013;47(1):49-52.

33. Cowan J, Sinton C, Varley A, Wians F, Haley R, Munford R. Gene therapy to prevent organophosphate intoxication. Toxicology and applied pharmacology. 2001;173(1):1-6.

34. Langemann H, Kabiersch A, Newcombe J. Measurement of low-molecular weight antioxidants, uric acid ,tyrosine and tryptophan in plaques and white matter from patients with multiple sclerosis. European neurology. 1992;32(5):248-52.

35. Martínez C, García-Martín E, Benito-León J, Calleja P, Díaz-Sánchez M, Pisa D, et al. Paraoxonase 1 polymorphisms are not related with the risk for multiple sclerosis.

Neuromolecular medicine. 2010;12(3):217-23. 
36. Adkins S, Gan K, Mody M, La Du B. Molecular basis for the polymorphic forms of human serum paraoxonase/arylesterase: glutamine or arginine at position 191, for the respective A or B allozymes. American journal of human genetics. 1993;52(3):598.

37. Mackness B, Mackness MI, Arrol S, Turkie W, Julier K, Abuasha B, et al. Serum paraoxonase (PON1) 55 and 192 polymorphism and paraoxonase activity and concentration in non-insulin dependent diabetes mellitus. Atherosclerosis. 1998;139(2):341-9.

38. Billecke S, Draganov D, Counsell R, Stetson P, Watson C, Hsu C, et al. Human Serum Paraoxonase (pon1) Isozymes Q and R Hydrolyze Lactones and Cyclic Carbonate Esters. Drug Metabolism and Disposition. 2000;28(11):1335.

39. Gaidukov L, Tawfik DS. High Affinity, Stability, and Lactonase Activity of Serum Paraoxonase PON1 Anchored on HDL with ApoA-I. Biochemistry. 2005;44(35):11843-54.

40. Roest M, Van Himbergen TM, Barendrecht AB, Peeters PHM, Van Der Schouw YT, Voorbij HAM. Genetic and environmental determinants of the PON-1 phenotype. European Journal of Clinical Investigation. 2007;37(3):187-96.

41. Hassan MA, Al-Attas OS, Hussain T, Al-Daghri NM, Alokail MS, Mohammed AK, et al. The Q192R polymorphism of the paraoxonase 1 gene is a risk factor for coronary artery disease in Saudi subjects. Molecular and cellular biochemistry. 2013;380(1-2):121-8.

42. Aviram M, Rosenblat M, Billecke S, Erogul J, Sorenson R, Bisgaier CL, et al. Human serum paraoxonase (PON 1) is inactivated by oxidized low density lipoprotein and preserved by antioxidants. Free Radical Biology and Medicine. 1999;26(7):892-904.

43. Leviev I, Negro F, James RW. Two alleles of the human paraoxonase gene produce different amounts of mRNA: an explanation for differences in serum concentrations of paraoxonase associated with the (Leu-Met54) polymorphism. Arteriosclerosis, thrombosis, and vascular biology. 1997;17(11):2935-9.

44. Leviev I, James RW. Promoter polymorphisms of human paraoxonase PON1 gene and serum paraoxonase activities and concentrations. Arteriosclerosis, thrombosis, and vascular biology. 2000;20(2):516-21.

45. Cherry N, Mackness M, Durrington P, Povery A, Dippnall M, Smith T, et al. Paraoxonase (PON1) polymorphisms in farmers attributing ill health to sheep dip. The Lancet. 2002;359(9308):763-4.

46. Rozek LS, Hatsukami TS, Richter RJ, Ranchalis J, Nakayama K, McKinstry LA, et al. The correlation of paraoxonase (PON1) activity with lipid and lipoprotein levels differs with vascular disease status. Journal of lipid research. 2005;46(9):1888-95.

47. Srinivasan SR, Li S, Chen W, Tang R, Bond MG, Boerwinkle E, et al. Q192R polymorphism of the paraoxanase 1 gene and its association with serum lipoprotein variables and carotid artery intima-media thickness in young adults from a biracial community: The Bogalusa Heart Study. Atherosclerosis. 2004;177(1):167-74.

48. van Himbergen TM, Roest M, de Graaf J, Jansen EH, Hattori H, Kastelein JJ, et al. Indications that paraoxonase-1 contributes to plasma high density lipoprotein levels in familial hypercholesterolemia. Journal of lipid research. 2005;46(3):445-51.

49. Van Himbergen T, Van Tits L, Roest M, Stalenhoef A. The story of PON1: how an organophosphate-hydrolysing enzyme is becoming a player in cardiovascular medicine. Neth J Med. 2006;64(2):34-8.

50. Shin BS, Oh SY, Kim YS, Kim KW. The paraoxonase gene polymorphism in stroke patients and lipid profile. Acta neurologica scandinavica. 2008;117(4):237-43.

51. Bassett C, Montine TJ. Lipoproteins and lipid peroxidation in Alzheimer's disease. The Journal of nutrition, health \& aging. 2003;7(1):24-9.

52. Durić G, Svetel M, Nikolaevic S, Dragadević N, Gavrilović J, Kostić V. Polymorphisms in the genes of cytochrome oxidase P450 2D6 (CYP2D6), paraoxonase 1 (PON1) and apolipoprotein E (APOE) as risk factors for Parkinson's disease. Vojnosanitetski pregled. 2007;64(1):25-30. 
53. Hadjigeorgiou GM, Malizos K, Dardiotis E, Aggelakis K, Dardioti M, Zibis A, et al. Paraoxonase 1 gene polymorphisms in patients with osteonecrosis of the femoral head with and without cerebral white matter lesions. Journal of orthopaedic research. 2007;25(8):108793.

54. Diekstra FP, Beleza-Meireles A, Leigh NP, Shaw CE, Al-Chalabi A. Interaction between PON1 and population density in amyotrophic lateral sclerosis. Neuroreport. 2009;20(2):18690.

55. Compston A, Coles A. Multiple sclerosis. Lancet (Lond, Engl) 372: 1502-1517. 2008.

56. LeVine $\mathrm{S}$. The role of reactive oxygen species in the pathogenesis of multiple sclerosis. Medical hypotheses. 1992;39(3):271-4.

57. Menini T, Gugliucci A. Paraoxonase 1 in neurological disorders. Redox Report. 2014;19(2):49-58.

58. Van Horssen J, Witte ME, Schreibelt G, De Vries HE. Radical changes in multiple sclerosis pathogenesis. Biochimica et Biophysica Acta (BBA)-Molecular Basis of Disease. 2011;1812(2):141-50.

59. Rodrigo L, Hernández AF, Lopez-Caballero JJ, Gil F, Pla A. Immunohistochemical evidence for the expression and induction of paraoxonase in rat liver, kidney, lung and brain tissue. Implications for its physiological role. Chemico-biological interactions. 2001;137(2):123-37.

60. Rozenberg O, Rosenblat M, Coleman R, Shih DM, Aviram M. Paraoxonase (PON1) deficiency is associated with increased macrophage oxidative stress: studies in PON1knockout mice. Free Radical Biology and Medicine. 2003;34(6):774-84.

61. Koch M, Ramsaransing GS, Arutjunyan AV, Stepanov M, Teelken A, Heersema DJ, et al. Oxidative stress in serum and peripheral blood leukocytes in patients with different disease courses of multiple sclerosis. Journal of neurology. 2006;253(4):483-7.

62. Hein K, Köhler A, Diem R, Sättler MB, Demmer I, Lange P, et al. Biological markers for axonal degeneration in CSF and blood of patients with the first event indicative for multiple sclerosis. Neuroscience letters. 2008;436(1):72-6.

63. Newcombe J, Li H, Cuzner M. Low density lipoprotein uptake by macrophages in multiple sclerosis plaques: implications for pathogenesis. Neuropathology and applied neurobiology. 1994;20(2):152-62. 